\title{
FAKTOR RISIKO KEJADIAN DIARE PADA BALITA DI KOTA BANJARMASIN
}

\section{Risk Factors of Diarrhea in Under Five Year Old Children in Banjarmasin City}

\author{
Kasman (1*), Nuning Irnawulan Ishak (1) \\ (1) Fakultas Kesehatan Masyarakat Universitas Islam Kalimantan MAB Banjarmasin
}

*Email Korespondensi: kasman.ph@gmail.com

\begin{abstract}
ABSTRAK
Kebanyakan kematian balita di negara berkembang salah satunya disebabkan oleh diare. Penyakit diare merupakan salah satu penyakit utama pada bayi dan anak di Indonesia. Penelitian ini bertujuan untuk mengetahui faktor resiko kejadian diare pada anak balita di Kota Banjarmasin. Target penelitian ini diharapkan dapat dilanjutkan dengan melakukan kegiatan pengabdian kepada masyarakat tentang kepemilikan jamban, pentingnya pemberian ASI Eksklusif serta pentingnya pemberian imunisasi pada balita. Rancangan penelitian ini menggunakan desain crossectional. Populasi penelitian adalah seluruh anak balita yang ada di Kota Banjarmasin sebanyak 54.746 balita. Teknik penarikan sampel secara multistage sampling dengan jumlah sampel sebanyak 188 balita. Pengumpulan data dengan melakukan wawancara langsung pada responden menggunakan kuesioner. Instrumen dalam penelitian ini yaitu menggunakan kuesioner dengan teknik wawancara. Analisis data menggunakan uji statistik Chi Square. Hasil penelitian ini menunjukkan bahwa terdapat hubungan yang bermakna antara kepemilikan jamban, pemberian ASI eksklusif, dan Imunisasi dengan kejadian Diare pada Balita di Kota Banjarmasin .
\end{abstract}

\section{Kata Kunci ～: Diare, Balita, Penyakit infeksi}

\begin{abstract}
Most of the deaths of under five year old children in developing countries is caused by diarrhea. Diarrhea is one of the main diseases in infants and children in Indonesia. This study aims to determine the risk factors for the incidence of diarrhea in under five year old children in the city of Banjarmasin. The target of this study is expected to be continued by carrying out community service activities regarding ownership of latrines, the importance of exclusive breastfeeding and the importance of immunization in under five year old children. The design of this study uses a cross sectional design. The study population was all children under five in the city of Banjarmasin as many as 54,746 children. The sampling technique is multistage sampling with a sample of 188 under five year old children. Data collection by conducting direct interviews with respondents using questionnaires. The instrument in this study is using a questionnaire with interview techniques. Data analysis using Chi Square statistical test. The results of this study indicate that there is a significant relationship between latrine ownership, exclusive breastfeeding, and immunization with the incidence of diarrhea in under five year old children in the city of Banjarmasin.
\end{abstract}

Keywords : Diarrhea, under five year old children, infectious diseases 


\section{PENDAHULUAN}

Penyakit diare dipengaruhi oleh beberapa faktor seperti lingkungan, agen penyebab penyakit, dan pejamu. Penyakit diare masih menjadi masalah kesehatan masyarakat yang penting karena merupakan penyumbang utama ketiga angka kesakitan dan kematian anak di berbagai negara termasuk Indonesia. Setiap anak mengalami episode serangan diare rata-rata 3,3 kali setiap tahun. Lebih kurang $80 \%$ kematian terjadi pada anak berusia kurang dari dua tahun ${ }^{1}$.

Diare merupakan suatu penyakit yang berbasis lingkungan. Ada 2 faktor yang dominan yaitu sarana air bersih, diare dapat terjadi bila seseorang menggunakan air minum yang sudah tercemar dari sumbernya, tercemar selama perjalanan sampai kerumah-rumah, atau tercemar pada saat disimpan dirumah, pencemaran dirumah terjadi bila tempat penyimpanan tidak tertutup atau apabila tangan yang tercemar menyentuh air pada saat mengambil air dari tempat penyimpanan dan melalui pembuangan tinja. Tinja yang sudah terinfeksi mengandung virus atau bakteri dalam jumlah besar. Bila tinja tersebut di hinggapi oleh binatang dan kemudian binatang tersebut hinggap dimakanan, maka makanan itu dapat menularkan diare ke orang yang memakannya ${ }^{2}$. Hasil penelitian menunjukkan bahwa ada hubungan antara lingkungan dengan kejadian diare ${ }^{3}$. Ada beberapa perilaku yang dapat meningkatkan resiko terjadinya diare yaitu tidak memberikan ASI secara penuh hingga umur 4-6 bulan pertama kehidupan, menggunakan botol susu formula, menyimpan makanan masak pada suhu kamar, air minum tercemar pada bakteri tinja, tidak mencuci tangan sesudah buang air besar, sebelum menjamah makanan 2 .

Beberapa hasil penelitian menunjukan bahwa terdapat hubungan yang bermakna antara faktor pemberian ASI Eksklusif, Status imunisasi dengan kejadian diare ${ }^{4}$, tempat pembuangan tinja yang tidak benar/penggunaan jamban sehat 1 , kebiasaan mencuci tangan 5, perilaku memberikan ASI, menggunakaan air bersih, mencuci tangan, menggunakan jamban dengan kejadian diare pada balita 6. Faktor risiko yang sering diteliti adalah faktor ling- kungan yaitu sarana air bersih dan jamban. Faktor risiko diare menurut faktor ibu yang bermakna adalah: pengetahuan, perilaku dan hygiene ibu. Faktor risiko diare menurut faktor anak: status gizi, dan pemberian ASI eksklusif. Faktor lingkungan berdasarkan sarana air bersih (SAB) dan sarana jamban 7 .

Penyakit diare di Kalimantan Selatan masih termasuk dalam salah satu golongan penyakit terbesar yang angka kejadiannya relatif cukup tinggi, keadaan ini di dukung oleh faktor lingkungan, terutama kondisi sanitasi dasar yang masih tidak baik, misalnya penggunaan air untuk keperluan sehari-hari yang tidak memenuhi syarat, jamban keluarga yang masih kurang dan keberadaannya kurang memenuhi syarat, serta kondisi sanitasi perumahan yang masih kurang dan tidak higienis. Di Kalimantan Selatan masih banyak ditemui kasus diare. Sebagai perbandingan kasus diare pada tahun 2008 sebanyak 54.316 kasus 2009 sebanyak 72.020 kasus, tahun 2010 sebanyak 52.908 kasus, serta tahun 2011 sebanyak $66.765^{8}$.

Penyakit diare di Kota Banjarmasin ditemukan sebanyak 12.531 kasus dan menempatkan sebagai kabupaten/kota yang memiliki penemuan penderita diare tertinggi. Tingginya kasus diare di Kota Banjarmasin, disebabkan oleh beberapa faktor, diantaranya adalah minimnya persediaan air bersih, kebiasaan mengkonsumsi air sungai yang tercemar dan tingkat pengetahuan masyarakat yang cukup rendah ${ }^{9}$. Dari data tersebut, peneliti tertarik melakukan penelitian untuk mengetahui faktor resiko kejadian diare pada anak balita di Kota Banjarmasin Provinsi Kalimantan Selatan. Tujuan dari penelitian ini adalah untuk mengetahui faktor resiko kejadian diare pada anak balita di Kota Banjarmasin Provinsi Kalimantan Selatan seperti kepemilikan jamban, pemberian ASI Eksklusif, dan status imunisasi.

\section{METODE PENELITIAN}

Jenis penelitian ini adalah survey analitik dengan menggunakan pendekatan cross sectional, variabel sebab akibat atau kasus yang terjadi pada objek penelitian diukur atau dikumpulkan secara simultan (dalam waktu yang bersamaan). Variabel independen dalam penelitian ini adalah kepemilikan jamban, pemberian ASI eksklusif, dan status imunisasi, sedangkan variabel dependennya 
adalah kejadian diare pada balita. Populasi dalam penelitian ini adalah semua anak balita yang berada di Banjarmasin sebanyak 54.746. Sampel dalam penelitian ini yaitu sebagian balita di Kota Banjarmasin Provinsi Kalimantan Selatan. Teknik pengambilan sampel menggunakan pendekatan multistage sampling dengan jumlah sampel 188. Pengumpulan data menggunakan kuesioner dengan melakukan wawancara langsung dengan responden. Data yang telah terkumpul kemudian diolah dan dianalisis dengan program SPSS.

\section{HASIL}

\section{Analisis Univariat}

Tabel 1 menunjukkan Kejadian Diare di Kota Banjarmasin tahun 2018 Sebanyak 43 balita $(22,9 \%)$ pernah menderita diare dalam 1 bulan terakhir. sebagian besar responden memiliki jamban yakni 97,9\%. Terdapat 146 balita $(22,3 \%)$ yang telah mendapatkan imunisasi dasar lengkap.

\section{Analisis Bivariat}

Tabel 2 menunjukkan bahwa proporsi balita yang pernah menderita diare selama 1 bulan terakhir lebih banyak pada responden yang tidak memiliki jamban yakni 75,0\% dibandingkan yang memiliki jamban $21,7 \%$. Sedangkan proporsi balita yang tidak diare lebih banyak pada responden yang memiliki jamban yakni 78,3\% dibandingkan yang tidak memiliki jamban 25,0\%. Hasil uji statistik didapatkan nilai $\mathrm{p}=0,038$ berarti terdapat hubungan yang bermakna antara kepemilikan jamban dengan kejadian diare selama 1 bulan terakhir di Kota Banjarmasin tahun 2018.

Tabel 3 menunjukkan bahwa proporsi kejadian diare selama 1 bulan terakhir lebih banyak pada balita yang tidak mendapatkan ASI ekslusif yakni 31,9\% dibandingkan dengan balita yang ASI ekslusif yakni 17,6\%. Sedangkan proporsi balita yang tidak diare lebih banyak pada balita ASI ekslusif yakni $82,4 \%$ dibandingkan balita tdiak ASI ekslusif $68,1 \%$. Hasil uji statistik didapatkan nilai $\mathrm{p}=$ 0,039 berarti terdapat hubungan yang bermakna antara pemberian ASI eksklusif dengan kejadian diare selama 1 bulan terakhir di Kota Banjarmasin tahun 2018.

Tabel 4 menunjukkan bahwa proporsi kejadian diare selama 1 bulan terakhir lebih banyak pada balita yang belum mendapatkan imunisasi lengkap yakni 38,1\% dibandingkan dengan balita yang mendapatkan imunisasi lengkap yakni $18,5 \%$. Sedangkan proporsi balita yang tidak diare lebih banyak pada balita telah mendapatkan imunisasi lengkap yakni 81,5\% dibandingkan balita yang belum mendapatkan imunisasi lengkap 61,9\%. Hasil uji statistik didapatkan nilai $\mathrm{p}=0,014$ berarti terdapat hubungan yang bermakna antara pemberian imunisasi dengan kejadian diare selama 1 bulan terakhir di Kota Banjarmasin tahun 2018.

\section{PEMBAHASAN}

Diare adalah suatu penyakit yang ditandai dengan meningkatnya frekuensi buang air besar (BAB) lebih dari 3 kali sehari, disertai dengan perubahan bentuk dan konsisten tinja penderita. Diare dibedakan menjadi dua berdasarkan waktu serangan (onset) yaitu diare akut dan diare kronik ${ }^{2}$. Hasil penelitian ini menunjukkan bahwa terdapat 43 balita (22,9\%) di Kota Banjarmasin tahun 2018 selama 1 bulan terakhir yang menderita diare. Kejadian diare di Kota Banjarmasin merupakan tertinggi di Provinsi Kalimantan Selatan ${ }^{9}$.

Beberapa hasil penelitian menunjukkan presentasi yang tinggi untuk kejadian diare pada balita. Sebanyak 45,3\% balita menderita diare di wilayah kerja Puskesmas Purwoharjo 1. Hasil penelitian yang dilakukan oleh Hardi A.R. dkk tahun 2012 menunjukkan sebanyak 46,8\% balita mengalami diare ${ }^{4}$. Tingginya kejadian diare pada balita dipengaruhi oleh banyak faktor diantaranya faktor lingkungan dan faktor perilaku termasuk dalam hal perilaku penggunaan jamban, pemberian ASI eksklusif, dan pemberian imunisasi.

Hasil penelitian ini menunjukkan bahwa sebagian besar responden $(94,6 \%)$ telah memiliki jamban. Hasil uji statistik didapatkan bahawa terdapat hubungan yang bermakna antara kepemilikan jamban dengan kejadian diare selama 1 bulan terakhir di Kota Banjarmasin tahun 2018. Penelitian ini sejalan dengan penelitian yang dilakukan oleh Lailatul tahun 2012 bahwa ketersediaan sarana pembuangan tinja memiliki hubungan dengan kejadian diare pada balita di wilayah kerja 
Puskesmas Purwoharjo Kabupaten Malang 1. Hal yang sama juga ditemukan oleh Rahmawati, dkk tahun 2012, penelitian Saleh, dkk tahun 2014 dan Putranti, dkk 2013 bahwa terdapat hubungan yang signifikan kepemilikan jamban dengan kejadian diare kepemilikan jamban 10,11,12.

Ditinjau dari sudut kesehatan lingkungan, kotoran manusia merupakan masalah yang sangat penting. Pembuangan tinja secara layak merupakan kebutuhan kesehatan yang paling diutamakan. Pembuangan tinja secara tidak baik dan sembarangan dapat mengakibatkan kontaminasi pada air, tanah, atau menjadi sumber infeksi, dan akan mendatangkan bahaya bagi kesehatan, karena penyakit yang tergolong waterborne disease akan mudah berjangkit 11 .

Tanpa adanya jamban akan mengakibatkan tinja buangan terbuka dan mudah dijangkau oleh vektor penyebab penyakit diare. Hal ini dapat mencemari makanan dan minuman secara langsung sehingga risiko munculnya peyakit diare semakin besar. Hasil krostabulasi silang antara kondisi jamban denganh kejadian diare menunjukkan bahwa terdapat hubungan yang bermakna. Dimana proporsi kejadian diare lebih banyak karena kondisi jamban yang tidak bersih. Hasil penelitian ini juga menunjukkan bahwa responden yang memiliki jamban bersih dan bebas dari vektor menunjukkan sebanyak 83,9\% tidak terjadi diare pada anak balitanya. Hal ini didukung oleh penelitian oleh bahwa terdapat pengaruh perilaku menggunakan jamban yang sehat terhadap kejadian diare.

ASI adalah makanan alamiah berupa cairan dengan kandungan gizi yang cukup dan sesuai untuk kebutuhan bayi, sehingga bayi tumbuh dan berkembang dengan baik. Air Susu ibu pertama berupa cairan bening berwarna kekuningan (kolostrum), sangat baik untuk bayi karena mengandung zat kekebalan terhadap penyakit 13. Hasil penelitian ini menunjukkan bahwa jumlah balita yang mendapatkan ASI ekslusif sebanyak 130 balita $(69,1 \%)$. Data ini tergolong tinggi jika dibandingkan dengan rata-rata cakupan ASI eksklusif nasional 35,73\% dan rata-rata cakupan ASI eksklusif Provinsi Kalimantan Selatan 36,78\% 14. Hasil penelitian yang dilakukan di Desa
Tanjung Harapan Kecamatan Alalak menunjukkan data yang kurang lebih sama yakni $43,6 \%{ }^{15}$.

Hasil uji statistik memperlihatkan bahwa terdapat hubungan yang bermakna antara pemberian ASI eksklusif dengan kejadian diare selama 1 bulan terakhir di Kota Banjarmasin tahun 2018. Beberapa hasil penelitian menunjukkan hasil yang sama dengan penelitian ini bahwa pemberian ASI eksklusif terbukti menurunkan kejadian diare pada balita $16,17,18,19$

Peran ASI belum mampu digantikan oleh susu formula seperti peran bakteriostatik, anti alergi atau peran psikososial. Pemberian ASI dapat membantu meningkatkan daya tahan tubuh. ASI mengandung sIgA, Limfosit T, Limfosit B, dan Laktoferin yang dapat merangsang peningkatan status imun anak ${ }^{20}$. Kandungan imunoglobulin dalam ASI membuat anak mendapatkan proteksi untuk terhindar dari penyakit diare. Hal ini membuat WHO merekomendasikan untuk memberikan hanya ASI saja sampai 6 bulan untuk keuntungan yang optimal bagi ibu dan bayi 21 .

Imunisasi adalah suatu usaha memberikan kekebalan bayi dan anak terhadap penyakit. Imunisasi suatu tindakan dengan sengaja memasukkan vaksin berupa mikroba hidup yang sudah dilemahkan. Dimana imunisasi dapat menimbulkan kekebalan terhadap tubuh. Imunisasi juga dapat dikatakan suatu tindakan dengan sengaja memasukkan vaksin yang berisi mikroba hidup yang sudah dilemahkan pada balita. Imunisasi merupakan salah satu pencegahan penyakit infeksi senus yang paling efektif 22 . Hasil penelitian ini menunjukkan bahwa masih terdapat 42 balita $(22,3 \%)$ yang belum mendapatkan imunisasi dasar lengkap. Hasil uji statistik menunjukkan terdapat hubungan yang bermakna antara pemberian imunisasi dengan kejadian diare selama 1 bulan terakhir di Kota Banjarmasin tahun 2018. Balita yang menderita diare dalam 1 bulan terakhir lebih banyak terjadi pada balita yang belum mendapatkan Imunisasi dasar lengkap. Hasil penelitian ini sejalan dengan penelitian yang dilakukan oleh Hardi A.R. tahun 2012 bahwa terdapat hubungan yang signifikan antara faktor imunisasi dengan kejadian diare ${ }^{4}$. 
Pemberian imunisasi bertujuan untuk melindungi tubuh bayi dan anak dari penyakit menular yang dapat membahayakan bagi ibu dan anak 22 . Pemberian imunisasi campak yaitu pemberian imunisasi campak segera setelah bayi berumur 9 bulan untuk mencegah agar bayi tidak terkena penyakit campak, karena anak yang sakit campak sering disertai diare sehingga pemberian imunisasi campak merupakan salah satu cara mencegah diare ${ }^{4}$.

\section{KESIMPULAN}

Terdapat hubungan yang bermakna antara Kepemilikan Jamban dengan Kejadian Diare di Kota Banjarmasin Provinsi Kalimantan Selatan. Terdapat hubungan yang bermakna antara Pemberian ASI Eksklusif dengan Kejadian Diare di Kota Banjarmasin Provinsi Kalimantan Selatan.Terdapat hubungan yang bermakna antara Status Imunisasi dengan Kejadian Diare di Kota Banjarmasin Provinsi Kalimantan Selatan. Diharapkan kepada masyarakat untuk menggunakan jamban saat BAB. Perlu dilakukan upaya kongkrit oleh Dinas Kesehatan Kota Banjarmasin dan jajarannya dalam meningkatkan kepemilikan Jamban oleh setiap rumah tangga. Kepada ibu-ibu agar memberikan ASI eksklusif dan imunisasi dasar lengkap kepada anaknya.

\section{UCAPAN TERIMA KASIH}

1. Direktorat Riset dan Pengabdian kepada Masyarakat, Ditjen Penguatan Riset dan Pengembangan Kementerian Riset, Teknologi, dan Pendidikan Tinggi.

2. Ketua Yayasan Universitas Islam Kalimantan (UNISKA) Banjarmasin

3. Rektor Universitas Islam Kalimantan (UNISKA) Banjarmasin

4. Kepala Lembaga Pusat penelitian dan Pengabdian pada Masyarakat Universitas Islam Kalimantan (UNISKA) Banjarmasin

5. Kepala Pusat Penelitian Universitas Islam Kalimantan (UNISKA) Banjarmasin

6. Dekan FKM Universitas Islam Kalimantan (UNISKA) Banjarmasin

7. Dinas Kesehatan Kota Banjarmasin

\section{DAFTAR PUSTAKA}

1. Mafazah, Lailatul (2013). Ketersediaan Sarana Sanitasi Dasar, Personal Hygiene Ibu Dan Kejadian Diare. Kemas Vol 8 Nomor 2 tahun 2013, hal 176-182

2. Widoyono (2011). Penyakit Tropis, Epidemiologi, Penularan, Pencegahan dan Pemberantasannya. Jakarta : Erlangga

3. Muhziadi (2012). Faktor-Faktor yang Berhubungan Dengan Kasus Diare di Pusk- esmas Ulee Kareng Kota Banda Aceh Tahun 2012. Jurnal Kesehatan Masyarakat

4. Hardi, A.R. (2012). Faktor-faktor yang Mempengaruhi Kejadian Diare pada Anak Batita di Wilayah Kerja Puskesmas Baranglompo Kecamatn Ujung Tanah. Journal online, Repository Unhas. Makasar

5. Evayanti N.K.E. dkk (2014). Faktor-faktor yang Berhubungan dengan Kejadian Diare pada Balita yang Berobat ke Badan Rumah Sakit Umum Tabanan. Jurnal Kesehatan Lingkungan. Vol 4 No.2 November 2014, hal 134-139

6. Kasaluhe, Meityn D. dkk (2014). FaktorFaktor yang Berhubungan dengan Kejadian Diare pada Balita di Wilayah Kerja Puskesmas Tahuna Timur Kabupaten Kepulauan Sangihe. Jurnal Online. Fakultas Kesehatan Masyarakat Universitas Sam Ratulangi Manado

7. Adisasmito, Wiku (2007). Faktor Risiko Diare pada Bayi dan Balita di Indonesia: Systematic Review Penelitian Akademik Bidang Kesehatan Masyarakat. MAKARA, KESEHATAN, VOL. 11, NO. 1, JUNI 2007: 110

8. Profil Kesehatan Provinsi Kalimantan Selatan (2012). Jumlah Kasus Diare di Provinsi Kalimantan Selatan. Banjarmasin

9. Profil Kesehatan Provinsi Kalimantan Selatan (2015). Jumlah Kasus Diare di kota Banjarmasin. Banjarmasin

10. Rahmawati, F. A. (2012). Hubungan Kepemilikan Jamban Dengan Kejadian Diare Pada Balita Di Desa Jatisobo Kecamatan Polokarto Kabupaten Sukoharjo. (Doctoral dissertation, Universitas Muhammadiyah Surakarta).

11. Saleh, Muh., dkk (2014). Hubungan Kondisi Sanitasi Lingkungan Dengan Kejadian Diare pada Anak Balita di Wilayah Kerja Puskesmas Baranti Kabupaten Sidrap Tahun 2013. Jurnal Kesehatan. Volume VII No. 1 tahun 2014, hal 221-233

12. Putranti, Dya Candra MS, dkk (2013) Hubungan Antara Kepemilikan Jamban dengan Kejadian Diare di Desa Karangagung Kecamatan Palang Kabupaten Tuban. Jurnal Kesehatan Lingkungan. Vol. 7, No. 1 Juli 2013, hal 5463

13. Maryunani, Anik (2013). Perilaku hidup bersih dan sehat (PHBS). Jakarta : Trans Info Media

14. Kementrian Kesehatan, R. I. (2017). Data dan Informasi Profil Kesehatan Indonesia tahun 2016. Kementrian Kesehatan Republik Indonesia, Pusdatin Kemenkes RI.

15. Hasniati, Y., Indah, M. F., Asrinawaty, A., \& 
Kasman, K. (2016). Determinan Pemberian Asi Eksklusif di Kabupaten Barito Kuala Kalimantan Selatan. Media Kesehatan Masyarakat Indonesia, 11(1), 39-43

16. Rahmadhani, E. P., Lubis, G., \& Edison, E. (2013). Hubungan Pemberian ASI Eksklusif dengan Angka Kejadian Diare Akut pada Bayi Usia 0-1 Tahun di Puskesmas Kuranji Kota Padang. Jurnal Kesehatan Andalas, 6 (2), 62-66

17. Wijayanti, W. (2010). Hubungan antara Pemberian Asi Eksklusif dengan Angka Kejadian Diare pada Bayi Umur 0-6 Bulan di Puskesmas Gilingan Kecamatan Banjarsari Surakarta (Doctoral dissertation, Universitas Sebelas Maret Surakarta).

18. Rizki, G. H. (2016). Hubungan Pemberian air susu ibu (ASI) dengan Kejadian Diare Pada Bayi 0-6 Bulan Di Puskesmas Kampung Dalam Pontianak Timur. ProNers, 3(1).

19. Kasaluhe, Meityn D. dkk (2014). FaktorFaktor yang Berhubungan dengan Kejadian Diare pada Balita di Wilayah Kerja Puskesmas Tahuna Timur Kabupaten Kepulauan Sangihe. Jurnal Online. Fakultas Kesehatan Masyarakat Universitas Sam Ratulangi Manado

20. Markum, A.H., 2002. Buku Ajar Ilmu Kesehatan Anak. Jilid 5. Jakarta: FKUI, p:68.

21. World Health Organization. (2012). The Optimal Duration of Exclusive Breastfeeding, Report of an Expert Consultation. Geneva, Switzerland: World Health Organization

22. Proverawati, dkk. (2010). Pengertian Manfaat dan Jenis Imunisasi. http:// www.kajianpustaka.com/2015/03/ pengertian-manfaat-dan-jenisimunisasi.html 


\section{LAMPIRAN}

Tabel 1. Distribusi Frekuensi Variabel Penelitian

\begin{tabular}{llcr}
\hline Variabel & Kategori & $\mathbf{n}$ & \% \\
\hline Diare & Ya & 43 & 22,9 \\
& Tidak & 145 & 77,1 \\
Kepemilikan Jamban & Tidak & 4 & 2,1 \\
\multirow{2}{*}{ ASI Eksklusif } & Ya & 184 & 97,9 \\
& Tidak & 69 & 36,7 \\
Imunisasi Campak & Ya & 119 & 63,7 \\
& Belum & 42 & 22,3 \\
& Sudah & 146 & 77,7 \\
\hline
\end{tabular}

Tabel 2. Hubungan Kepemilikan Jamban dengan Kejadian Diare di Kota Banjarmasin Tahun 2018

\begin{tabular}{|c|c|c|c|c|c|c|c|}
\hline \multirow{3}{*}{$\begin{array}{c}\text { Kepemilikan } \\
\text { Jamban }\end{array}$} & \multicolumn{4}{|c|}{ Diare } & \multirow{2}{*}{\multicolumn{2}{|c|}{ Total }} & \multirow{3}{*}{ Uji Statistik } \\
\hline & \multicolumn{2}{|c|}{ Ya } & \multicolumn{2}{|c|}{ Tidak } & & & \\
\hline & $\mathbf{n}$ & $\%$ & $\mathbf{n}$ & $\%$ & $\mathbf{N}$ & $\%$ & \\
\hline Tidak & 3 & 75,0 & 1 & 25,0 & 4 & 100 & \\
\hline Ya & 40 & 21,7 & 144 & 78,3 & 184 & 100 & $p=0,038$ \\
\hline Total & 43 & 22,9 & 145 & 77,1 & 188 & 100 & \\
\hline
\end{tabular}

Tabel 3. Hubungan Pemberian ASI Eksklusif dengan Kejadian Diare di Kota Banjarmasin Tahun 2018

\begin{tabular}{|c|c|c|c|c|c|c|c|}
\hline \multirow{3}{*}{ ASI Ekslusif } & \multicolumn{4}{|c|}{ Diare } & \multirow{2}{*}{\multicolumn{2}{|c|}{ Total }} & \multirow{3}{*}{ Uji Statistik } \\
\hline & \multicolumn{2}{|c|}{ Ya } & \multicolumn{2}{|c|}{ Tidak } & & & \\
\hline & $\mathbf{n}$ & $\%$ & $\mathbf{n}$ & $\%$ & $\mathbf{N}$ & $\%$ & \\
\hline Tidak & 22 & 31,9 & 47 & 68,1 & 69 & 100 & \\
\hline Ya & 21 & 17,6 & 98 & 82,4 & 119 & 100 & $p=0,039$ \\
\hline Total & 43 & 22,9 & 145 & 77,1 & 188 & 100 & \\
\hline
\end{tabular}

Tabel 4. Hubungan Pemberian Imunisasi dengan Kejadian Diare di Kota Banjarmasin Tahun 2018

\begin{tabular}{lcccccccc}
\hline \multirow{2}{*}{ Imunisasi } & \multicolumn{4}{c}{ Diare } & \multicolumn{2}{c}{ Total } & \multirow{2}{*}{ Uji Statistik } \\
\cline { 2 - 7 } & \multicolumn{3}{c}{ Ya } & \multicolumn{2}{c}{ Tidak } & & \% & \\
\cline { 2 - 7 } & $\mathbf{n}$ & $\mathbf{\%}$ & $\mathbf{n}$ & $\mathbf{\%}$ & $\mathbf{N}$ & $\mathbf{\%}$ & \\
\hline Belum Lengkap & 16 & 38,1 & 26 & 61,9 & 42 & 100 & \\
Lengkap & 27 & 18,5 & 119 & 81,5 & 146 & 100 & $\mathrm{p}=0,014$ \\
Total & 43 & 22,9 & 145 & 77,1 & 188 & 100 & \\
\hline
\end{tabular}

